\title{
Canola Meal Adhesive for the Production of Wood Fiber Insulation Boards Using Hot-Air/Hot-Steam-Process
}

\author{
Kolja Ostendorf ${ }^{1}$, Julian Haerkötter ${ }^{2}$ \& Markus Euring ${ }^{1}$ \\ ${ }^{1}$ Department of Forest Botany and Tree Physiology, Georg-August-University of Goettingen, Germany \\ ${ }^{2}$ Department of Molecular Wood Biotechnology and Technical Mycology, Georg-August-University of \\ Goettingen, Germany \\ Correspondence: Markus Euring, Department of Forest Botany and Tree Physiology, Georg-August-University of \\ Goettingen, D-37077 Goettingen, Germany. Tel: +49 55139 23323. E-mail: meuring@gwdg.de
}

Received: January 5, 2021

Accepted: March 31, 2021

Online Published: June 30, 2021

doi:10.5539/jmsr.v10n1p28

URL: https://doi.org/10.5539/jmsr.v10n1p28

\begin{abstract}
Canola meal as a by-product from the vegetable oil production provides a protein-rich material which is available in large quantities but with limited areas for application. The objective of this study was to investigate the possibility of utilizing canola meal adhesive for the production of wood fiber insulation boards (WFI) using the hot-air/hot-steam-process. WFI with two different thicknesses $(40 / 60 \mathrm{~mm})$ and different densities $\left(110 / 140 / 160 / 180 \mathrm{~kg} / \mathrm{m}^{3}\right)$ were manufactured. The testing focused on their physical-mechanical properties such as internal bond strength (IB), compressive strength (CS) and short-term water absorption (ST-WA) measured according to European standards. For a better understanding of the material and curing dynamics, the canola meal was analyzed on its protein content, lignin and pentosane content as well as its extractives content using hot water, cold water and successive extraction. Using a canola meal based adhesive resulted in promising results for IB and CS up to density of $140 \mathrm{~kg} / \mathrm{m}^{3}$. Nonetheless, there is place for improvement for the ST-WA.
\end{abstract}

Keywords: Adhesive, Canola Meal, Hot-Air/Hot-Steam-Process, Physical Mechanical Properties, Protein, Wood Fiber Insulation Board

\section{Introduction}

Insulation materials made from wood fibers can provide a resource-saving alternative to materials such as mineral fibers, expanded glass, foam glass, calcium silicate, perlite, expanded clay, natural pumice, rock wool, polystyrene or sheep's wool (Eichhorn, 2017). The material wood is in itself a hygroscopic material (Lundgren, 1958). Once the moisture content of wood exceeds $20 \%$ of total weight, its insulating properties are lost (Informationsdienst Holz, 2007). The usage should therefore be limited on areas where no permanent higher moisture content is to be expected. In order to reduce the water absorption, polymeric diphenylmethane diisocyanate (pMDI) is currently mainly used as a binder for the industrial production of wood fiber insulation boards (WFI), in particular, through the ability of forming strong and durable covalent bonds with wood components (Zhou \& Frazier, 2001; Frihart, 2013).

However, pMDI and other polyurethanes (PU) on the market are based on fossil fuels (Tsuomis, 1991; Türk, 2014). In addition, pMDI is considered problematic in terms of processing since it adheres to almost all surfaces and thus, a release agent is required during processing. Furthermore, pMDI is classified as harmful to health: vapors, gases, aerosols and dust particles can cause respiratory problems, skin contact can lead to allergic reactions and bronchial hypersensitivity (Bundeministerium für Gesundheit, 2004). Besides the sensitizing effect according to TRGS 401 there is also the possibility of contact eczema (Bundesanstalt für Arbeitsschutz und Arbeitsmedizin, 2009). For this reason, both industry and science are searching for equivalent, alternative binders.

One possible opportunity is to use plant proteins derived from canola. There are several studies using modified and unmodified protein isolates (Li et al., 2012; 2017; Hale, 2013; Wang et al., 2014; Bandara et al., 2017) or canola meal together with phenol-formaldehyde-resin (Yang et al., 2010; 2011; 2012; 2014) as adhesive for wood or wood composites. The advantage of using canola meal is to avoid expensive, low-yield and chemical-rich protein isolation (Elstner \& Stein 1982).Therefore, this study focusses on the usage of solubilized 
canola meal as adhesive for the production of WFI for the first time by means of using the innovative hot-air/hot-steam-curing-technology developed by Euring and Kharazipour (2013).

As the third largest oil seed crop (McVetty \& Duncan, 2015), canola seeds provides $40 \%$ oils and $60 \%$ seed meal with a protein content between 35-40 \% (Raymer, 2002; Booth \& Gunstone, 2004). The protein composition consists of $50 \%$ cruciferin, $20-40 \%$ napin and up to $8 \%$ oleosin (Von der Haar et al., 2014). While napin constitutes a water-soluble albumin with a secondary structure, cruciferin is a more complex salt-soluble globulin with a quaternary structure (Fahs \& Louarn, 2013; Von der Haar et al., 2014). The annual (2019) worldwide production of canola seeds or rapeseed is 70.5 Mio. $t$ (FAOSTAT 2020). This equivalents to a production of 45.7 Mio. t. of seed meal $(60 \%)$ as by-product and is therefore available in large quantities. According to a study from van Zeist et al. (2012) the costs amounts to $213 \$ / t$ for canola meal.

Canola meal consists about $46.5 \%$ of carbon from photosynthesis (Peterson \& Hustrulid, 1997). Wooden biomass stores about $50 \%$ of total weight in carbon (Lamlom \& Savidge, 2003). Burning or feeding canola meal would end up in neutral carbon food print, whilst using wood fibers and canola meal for insulation purpose, the amount of carbon would remain stored within its whole utilization period.

\section{Material and Methods}

The native canola expeller used in this study was obtained by Kleeschulte GmbH \& Co. KG (Büren, Germany). The used TMP wood fibers with a moisture content of $10-12 \%$ were obtained by GUTEX Holzfaserplattenwerk H. Henselmann GmbH \& Co. KG (Waldshut-Tiengen, Germany) which constitutes a mixture of $80 \%$ norway spruce (Picea abies) and 20\% silver fir (Abies alba).

\subsection{Canola Meal Adhesive Preparation}

In the first step, the canola meal adhesive was prepared. Therefore, the canola expeller was crushed to about $<5$ $\mathrm{mm}$ sized pieces and subsequently sieved. The green-yellowish meal fractions $<400 \mu \mathrm{m}$ were used for adhesive production, whereas bigger fractions were discarded containing mostly hull fragments and crude fiber. To evaluate the canola meal characteristics, nitrogen analysis according to Kjeldahl was carried out as well as lignin analysis according to TAPPI standard (1985), hot and cold water extractions, successive extraction as well as pentosane content determination. The adhesive was produced by mixing $17.5 \%$ canola meal together with $17.5 \%$ urea, $50 \%$ water and $15 \%$ sodium hydroxide (1M) solution. After stirring for about 20 minutes the relatively high viscous dispersion with total solids content of $35 \%$ and $\mathrm{pH}$ value of 12.5 was ready to use. In order to enhance the hydrophobicity of the produced boards, $2 \%$ (based on absolute dry wood fibers) of a paraffin emulsion (HydroWax Syntec Blue, Sasol Germany GmbH, Hamburg, Germany) was added to the canola meal dispersion.

\subsection{Manufacture of Wood Fiber Insulation Boards (WFI)}

In the second step, the adhesive mixture was added to the fibers on a resin load of $15 \%$ (solids) based on absolute dry wood fibers. By means of an atomizer spray nozzle, the adhesive was blended with wood fibers at a blending unit of the institutes own pilot plant for MDF production. Then, the treated fibers were loosened and dried via flash tube dryer at $50^{\circ} \mathrm{C}$ to a moisture content of $16-17 \%$. The fibers were then compressed to $40 \mathrm{~mm}$, or $60 \mathrm{~mm}$, respectively, and were then transferred to the hot-air/hot-steam unit. The curing of WFI was done like described in Ostendorf et al. (2020) with temperatures of $160-170^{\circ} \mathrm{C}$. As reference, WFI were manufactured with $4 \%$ pMDI using same treatment. Following the industrial technology, a further pMDI reference was produced using merely hot-steam injection for about 60s according to Ostendorf et al. (2020). The attempt of curing canola adhesive bonded fibers with solely hot-steam injection failed due to insufficient hardening of the boards.

For each WFI variant, three boards were manufactured and conditioned to equilibrium moisture content at $23^{\circ} \mathrm{C}$ and $50 \%$ RH. Afterwards the edges of the WFI were trimmed and test sample were cut-to-size according to the EN standards. The samples were analyzed conferring to the following physical-mechanical properties: internal bond (IB) strength test (EN 1607 2013), compressive strength (CS) test (EN 826 2013) and short term (24h) water absorption (ST-WA) during partial immersion (EN 1609 2013). Furthermore, samples of cured WFI were analyzed using cold and hot water extraction to evaluate changes in $\mathrm{pH}$ and extractives content when treating fibers with canola meal adhesive.

\section{Results and Discussion}

\subsection{Canola Meal Characteristics}

The results for the canola meal analysis are shown in table (1). The protein content for meal fractions $<400 \mu \mathrm{m}$ according to the Kjeldahl method is $36.7 \%$. In comparison, the original expeller shows a protein content of 30.6\% (Landwirtschaftliche Untersuchungs- und Forschungsanstalt Nordrhein-Westfalen, 2018). Thus, by 
grinding and sieving, it is possible to increase protein content by removing unwanted components such as residues of hull fragments. This can be confirmed by the very low measured lignin content $(0.7 \%)$ of the meal. In contrast, a study of Briones et al. (2010) determined a lignin content of up to $16 \%$ for canola meal. This distinct difference in lignin content indicates, that most part of hull fragments were removed by sieving canola meal, considering, that the hulls cover $95 \%$ of canola lignin content (Carré et al., 2016).

A pentosane content of $2.8 \%$ is measured for canola meal. A study by Clandinin and Rao (1970) found a pentosane content of $8.3 \%$ for canola meals, showing a reduction by milling and sieving canola expeller. By extracting canola meal with petrol ether, $13.1 \%$ of lipids and fatty acids are removed which is mostly congruent with the value for expeller $(13.9 \%$, Landwirtschaftliche Untersuchungs- und Forschungsanstalt Nordrhein-Westfalen, 2018). Within this successive extraction method, $22.2 \%$ extractives are determined. In contrast, by extracting with merely cold or hot water respectively, extractives of $23.0 \%$ or $27.8 \%$ are detected. The $\mathrm{pH}$ measurement for the liquid phase of the mentioned extractions show $\mathrm{pH}$ values of 5.7 (cold) and 5.3 (hot), therefore in the acid range. The question occurs, if the measured components besides protein have an influence of the gluing properties on the canola meal adhesive. The strong alkaline treatment with $\mathrm{NaOH}$ might lead to a decomposition of the components as stated by Yang et al. (2014) which might end up in loosing additional adhesive effects (e.g. holocelluloses).

When canola meal is mixed together with water, urea and $\mathrm{NaOH}$, it is necessary to generate a sort of fluid and sprayable solution. Therefore, this study focused on the usage of $<400 \mu \mathrm{m}$ fractions due to fact, that water uptake increases with decreasing particle sizes (Ranjbar, 2013). Using smaller particle sizes, for instance $<200 \mu \mathrm{m}$, would consequently end up in an unsuitable not-sprayable slurry.

Table 1. Results for canola meal analysis

\begin{tabular}{llr}
\hline & & Canola meal (<400 $\boldsymbol{\mu m}_{\mathbf{m}}$ \\
\hline Moisture content (\%) & & 8.5 \\
Pentosane (\%) & & 2.3 \\
Lignin (\%) & & 0.7 \\
Nitrogen (N) content (\%) & & 5.9 \\
Protein (N6.25) content (\%) & pH & 36.7 \\
Hot water-extraction & Extractives (\%) & 5.3 \\
& pH & 27.8 \\
Cold water-extraction & Extractives (\%) & 5.7 \\
& Petrol ether & 23.0 \\
Successive extraction (\%) & Diethyl ether & 13.1 \\
& Acetone-water & 0.4 \\
& Ethanol-water & 4.5 \\
& & 4.2 \\
\hline
\end{tabular}

\subsection{Analysis of Wood Fiber}

The results of the analysis of WFI specimen treated with alkaline canola meal adhesive and native wood fibers are shown in figure (1). The $\mathrm{pH}$ changes from acid into neutral range (6.94) for cured WFI in comparison to native wood fibers. It is anticipated, that canola proteins are solubilized in alkaline environment (Li et al., 2011; Hale, 2013). Furthermore, the proteins starts to unfold and their contact area increased (Hale, 2013; Li et al., 2017). The authors assume that, when it comes to contact with acidic wood fibers, the proteins precipitate on fiber surfaces. By subsequently compressing and high temperature treatment within hot-air/hot-steam-process, the protein cures by denaturation and interaction with wood fibers. Since cruciferin has a higher molecular weight than napin and therefore a higher unfolding-length, it is considered to have a higher adhesion strength (Fahs \& Louarn 2013).

The content of extractives is more than tripled by the extractive-rich adhesive; also considering additional $2 \%$ hydrophobic agent (solids content $=55 \%$ ) within the adhesive formulation. With a $\mathrm{pH}$-neutral ranged panel 
product, an interaction with $\mathrm{pH}$-sensitive construction materials like iron, where the corrosion rate increases with $\mathrm{pH}>9$ (Kaesche, 1970), is less critical.

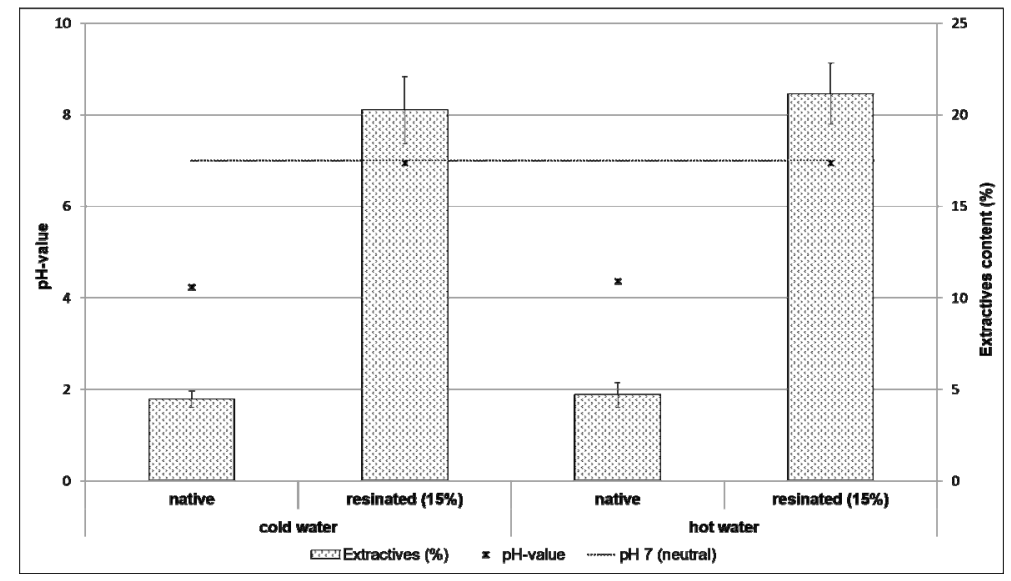

Figure 1. $\mathrm{pH}$-value and extractives content of native wood fibers and cured WFI using $15 \%$ canola meal adhesive after cold and hot water extraction $(n=3)$

\subsection{Physical-Mechanical Properties}

The results for the physical-mechanical properties of the WFI are summarized in table (2). The general observations are a decrease in IB and CS strength as well as decreased ST-WA with reducing densities, which constitutes a well-known correlation between density and physical-mechanical properties (Niemz \& Wagenführ, 2018). Moreover, there are no indicative changes in physical-mechanical properties between two different panel thicknesses of 40 and $60 \mathrm{~mm}$.

The results show that the canola meal bonded WFI are comparable to the pMDI-references cured via hot-steam and to the GUTEX industrial products regarding IB and CS. Exceptions are results for CS at lowest density of $110 \mathrm{~kg} / \mathrm{m}^{3}(44.9 \mathrm{kPa}$ for $40 \mathrm{~mm}$ and $43.6 \mathrm{kPa}$ for $60 \mathrm{~mm}$ ). The denaturation temperature of canola protein is about $150^{\circ} \mathrm{C}$ (Hale, 2013). Hale (2013) also found that, when press temperature increasingly distinct from denaturation temperature, higher adhesion strength occurs due to enhanced interface reaction between wood and proteins. Therefore, the innovative hot-air/hot-steam-process is the proper way to cure natural based adhesives for the production of WFI (Euring et al., 2015; Kirsch et al., 2018; Ostendorf et al., 2020).

In contrast, the pMDI reference cured via hot-air/hot-steam, achieved best results over all conducted tests with the exception of the variants with density of $180 \mathrm{~kg} / \mathrm{m}^{3}$ and board thicknesses of 40 and $60 \mathrm{~mm}$. Here, the canola meal bonded boards show impressive $328.5 \mathrm{kPa}$ of $60 \mathrm{~mm}$ thick boards. The enhancement of panel quality by using hot-air/hot-steam-process and pMDI as binder is well documented in several studies (Euring \& Kharazipour, 2013; Euring et al., 2015; Kirsch et al., 2018; Ostendorf et al., 2020).

The high ST-WA over all densities and thicknesses is problematic, despite the addition of $2 \%$ hydrophobic agent. Frihart and Birkeland (2014) found that carbohydrates in soy flour adhesives are responsible for poor water resistance of protein-to-wood-bonding. Since canola meal consist of up to $50 \%$ of carbohydrates (Bell 1984), a negative impact on ST-WA has to be considered. Additionally, $\mathrm{NaOH}$ as highly hygroscopic substance is able to absorb humidity from the surrounding environment which can be accumulated between wood fibers and therefore affect the water absorption (Hollemann et al., 2017). On the other hand, the addition of $\mathrm{NaOH}$ is an important measure to hydrate and properly unfold the canola protein up to tertiary structure, to expose the functional groups for enhanced interaction between wood and protein (Hale, 2013; Li et al., 2017). This can be explained by polar and non-polar groups of the protein chains which are able to interact with polar hydroxyl-groups of wood. Thereby, the non-polar groups are considered as hydrophobic. The more hydrophobic groups are present, the stronger and more water-resistant is the protein-wood-bonding. Unfortunately, canola provides a low hydrophobic protein ( $\mathrm{Li}$ et al., 2017). Sun (2005) found that soy protein isolate modification using urea leads to higher amount of water resistant bonds. As soy protein is expected to have a similar functionality as canola ( $\mathrm{Li}$ et al., 2012), urea is used in this study as further modifying agent besides $\mathrm{NaOH}$. Nonetheless, a beneficial effect might be disabled by the presence of carbohydrates, which is presented in the study of Frihart and Birkeland (2014) for soyflour adhesives. This might be due to steric hindrance or the high 
viscosity of the flour based adhesive (Frihart \& Birkeland, 2014). The measured oil content of the used canola meal of $13.1 \%$ might have a beneficial effect on water absorption. Nonetheless, the results show that the occurred protein-wood-bonding, mostly characterized by electrostatic interactions, hydrogen bonds and van der Waals forces (Fahs \& Louarn, 2013), are sufficient for good initial mechanical properties (IB and CS). For further investigations, the addition of crosslinking-agents such as formaldehyde or glyoxal should be considered to improve water resistance as well as mechanical properties.

Table 1. Properties (Internal bond strength (IB), compressive strength (CS) and short-term water absorption (ST-WA) of canola meal bonded WFI in comparison to pMDI bonded WFI and industrially manufactured product. The standard deviation is shown in parentheses

\begin{tabular}{|c|c|c|c|c|c|}
\hline \multirow[t]{2}{*}{$\begin{array}{l}\text { Density } \\
\left(\mathrm{kg} / \mathrm{m}^{3}\right)\end{array}$} & \multirow[t]{2}{*}{ Variant } & \multirow[t]{2}{*}{$\begin{array}{l}\text { Thickness } \\
(\mathrm{mm})\end{array}$} & \multirow{2}{*}{$\begin{array}{l}\text { IB } \\
(\mathrm{kPa}) \\
n=30\end{array}$} & \multirow{2}{*}{$\begin{array}{l}\text { CS } \\
(\mathrm{kPa}) \\
n=24\end{array}$} & \multirow{2}{*}{$\begin{array}{l}\text { ST-WA } \\
\left(\mathrm{kg} \mathrm{m}^{-2}\right) \\
n=9\end{array}$} \\
\hline & & & & & \\
\hline \multirow[t]{7}{*}{110} & Canola & 40 & $5.3( \pm 1.0)$ & $44.9( \pm 14.2)$ & $3.3( \pm 0.9)$ \\
\hline & & 60 & $5.0( \pm 1.4)$ & $43.6( \pm 9.2)$ & $1.3( \pm 0.4)$ \\
\hline & pMDI HS $^{\mathrm{a}}$ & 40 & $4.3( \pm 1.1)$ & $48.1( \pm 17.7)$ & $1.2( \pm 0.8)$ \\
\hline & & 60 & $5.9( \pm 0.8)$ & $57.0( \pm 9.6)$ & $1.3( \pm 0.4)$ \\
\hline & pMDI HA/HS ${ }^{\mathrm{b}}$ & 40 & $5.7( \pm 2.0)$ & $49.5( \pm 19.7)$ & $0.5( \pm 0.1)$ \\
\hline & & 60 & $11.9( \pm 4.7)$ & $81.3( \pm 9.7)$ & $0.6( \pm 0.1)$ \\
\hline & GUTEX $^{\mathrm{c}}$ & $40 / 60$ & 5 & 50 & $\leq 2$ \\
\hline \multirow[t]{7}{*}{140} & Canola & 40 & $7.8( \pm 1.6)$ & $74.5( \pm 17.5)$ & $3.7( \pm 0.9)$ \\
\hline & & 60 & $11.5( \pm 1.8)$ & $85.8( \pm 16.2)$ & $3.5( \pm 1.3)$ \\
\hline & pMDI HS & 40 & $8.4( \pm 3.1)$ & $80.2( \pm 19.1)$ & $1.0( \pm 0.2)$ \\
\hline & & 60 & $13.5( \pm 4.4)$ & $124.5( \pm 15.1)$ & $2.2( \pm 0.6)$ \\
\hline & pMDI HA/HS & 40 & $19.4( \pm 2.3)$ & $140.2( \pm 14.7)$ & $0.6( \pm 0.1)$ \\
\hline & & 60 & $14.3( \pm 4.8)$ & $146.9( \pm 14.6)$ & $0.9( \pm 0.1)$ \\
\hline & GUTEX $^{\mathrm{d}}$ & $40 / 60$ & 7.5 & 70 & $\leq 2$ \\
\hline \multirow[t]{7}{*}{160} & Canola & 40 & $12.7( \pm 3.7)$ & $119.2( \pm 16.0)$ & $4.6( \pm 1.2)$ \\
\hline & & 60 & $15.8( \pm 3.9)$ & $128.5( \pm 16.3)$ & $4.2( \pm 1.3)$ \\
\hline & pMDI HS & 40 & $25.2( \pm 6.2)$ & $146.6( \pm 35.3)$ & $1.4( \pm 0.8)$ \\
\hline & & 60 & $18.3( \pm 2.7)$ & $122.7( \pm 15.8)$ & $1.7( \pm 0.5)$ \\
\hline & pMDI HA/HS & 40 & $25.9( \pm 2.8)$ & $192.1( \pm 21.7)$ & $0.9( \pm 0.2)$ \\
\hline & & 60 & $26.6( \pm 3.1)$ & $168.1( \pm 15.8)$ & $0.9( \pm 0.3)$ \\
\hline & GUTEX $^{\mathrm{e}}$ & $40 / 60$ & 10 & 100 & $\leq 1$ \\
\hline \multirow[t]{7}{*}{180} & Canola & 40 & $24.2( \pm 4.1)$ & $240.6( \pm 55.4)$ & $4.8( \pm 1.3)$ \\
\hline & & 60 & $24.0( \pm 2.8)$ & $328.5( \pm 34.3)$ & $4.5( \pm 1.4)$ \\
\hline & pMDI HS & 40 & $28.6( \pm 5.8)$ & $181.1( \pm 33.2)$ & $3.4( \pm 0.2)$ \\
\hline & & 60 & $27.4( \pm 2.9)$ & $207.4( \pm 39.7)$ & $1.8( \pm 1.1)$ \\
\hline & pMDI HA/HS & 40 & $31.1( \pm 6.5)$ & $208.7( \pm 42.5)$ & $0.9( \pm 0.1)$ \\
\hline & & 60 & $31.5( \pm 4.3)$ & $255.0( \pm 37.9)$ & $0.9( \pm 0.1)$ \\
\hline & GUTEX $^{\mathrm{f}}$ & $40 / 60$ & 20 & 150 & $\leq 1$ \\
\hline
\end{tabular}

${ }^{a}$ pMDI-reference cured via hot-steam (HS). ${ }^{b}$ pMDI-reference cured via hot-air/hot-steam (HA/HS). ${ }^{\mathrm{c}}$ GUTEX-reference product Thermosafe homogen ${ }^{\circledR}$. ${ }^{\mathrm{d}}$ GUTEX-reference product Multitherm ${ }^{\mathbb{B}}$. ${ }^{\mathrm{e}}$ GUTEX-reference product Thermowall ${ }^{\circledR}$. ${ }^{\mathrm{f}}$ GUTEX-reference product Ultratherm ${ }^{\circledR}$. 


\section{Conclusions}

This pioneering study shows that it is possible to produce a canola meal based adhesive without expensive protein isolation for the manufacture of WFI. It is possible to increase protein content of canola meal by crushing and sieving to $>400 \mu \mathrm{m}$ fractions. The protein-rich canola meal based adhesive constitutes a suitable alternative to pMDI for the production of wood fiber insulation boards up to a density of $140 \mathrm{~kg} / \mathrm{m}^{3}$ in regard to IB and CS. The curing depends on high temperatures, which can be realized by means of hot-air/hot-steam process. By generating temperatures far beyond $100^{\circ} \mathrm{C}$, a proper protein denaturation and thus enhanced mechanical properties are obtained. The alkaline adhesive is buffered by acidic wood fibers. Carbohydrates within the canola meal might provide additional bonding properties but also decreased water resistance. By decreasing the densities, the physical-mechanical properties decreases as well. But still, there is a need for further improvements, especially regarding ST-WA.

\section{Acknowledgements}

The authors are grateful to the financial support by the Deutsche Forschungsgemeinschaft (DFG) given to Markus Euring (EU 124/3-1). Additionally, the authors would like to thank Mrs. Patricia Schneider and Mr. Christian Kerl for the technical support.

\section{Conflict of interests}

The authors declare that there is no conflict of interests regarding the publication of this paper.

\section{References}

Bandara, N., Esparza, Y., \& Wu, J. (2017). Exfoliating nanomaterials in canola protein derived adhesive improves strength and water resistance. RSC advances, 7(11), 6743-6752. https://doi.org/10.1039/C6RA27470F

Bell, J. M. (1984). Nutrients and toxicants in rapeseed meal: A review. Journal of Animal Science, 58(4), 996-1010. https://doi.org/10.2527/jas1984.584996x

Booth, E. J., \& Gunstone, F. D. (2004). Rapeseed and Rapeseed Oil: Agronomy, production, and trade. In F. D. Gunstone (Ed.), Rapeseed and canola oil: Production, processing, properties and uses (pp. 1-15). CRC Press.

Briones, R., Serrano, L., Llano-Ponte, R., \& Labidi, J. (2011). Polyols obtained from solvolysis liquefaction of biodiesel production solid residues. Chemical Engineering Journal, 175, 169-175. https://doi.org/10.1016/j.cej.2011.09.090

Bundesanstalt für Arbeitsschutz und Arbeitsmedizin. (2009). Technische Regeln für Gefahrstoffe "Isocyanate Gefährdungsbeurteilung und Schutzmaßnahmen". TRGS 430. Retrieved May 4, 2020 from https://www.baua.de/DE/Angebote/Rechtstexte-und-Technische-Regeln/Regelwerk/TRGS/TRGS-430.html

Bundesministerium für Gesundheit. (2004). Merkblatt zu der Berufskrankheit Nr. 1315 der Anlage zur Berufskrankheiten-Verordnung (BKV) "Erkrankungen durch Isocyanate, die zur Unterlassung aller Tätigkeiten gezwungen haben, die für die Entstehung, die Verschlimmerung oder das Wiederaufleben der Krankheit ursächlich waren oder sein können". Retrieved May 4, 2020, from https://www.baua.de/DE/Angebote/Rechtstexte-und-Technische-Regeln/Berufskrankheiten/Merkblaetter.ht $\mathrm{ml}$

Carré, P., Citeau, M., Robin, G., \& Estorges, M. (2016). Hull content and chemical composition of whole seeds, hulls and germs in cultivars of rapeseed (Brassica napus). OCL, 23(3), A302 1-8. https://doi.org/10.1051/ocl/2016013

Clandinin, D. R., \& Rao, P. V. (1970). Pentosans in prepress-solvent and solvent processed rapeseed meal. Poultry Science, 49(6), 1741-1742. https://doi.org/10.3382/ps.0491741

Eichhorn, S. (2017). Entwicklung neuartiger mit Polyurethan gebundener Holzfaserdämmstoffe geringer Rohdichte (Doctoral dissertation). Georg-August-Universität Göttingen, Germany.

Elstner, F., \& Stein, W. (1982). Entwicklung eines Verfahrens zur Gewinnung von Protein-Isolaten aus Rapssaat. Fette, Seifen, Anstrichmittel, 84(10), 396-399. https://doi.org/10.1002/lipi.19820841007

EN 1607. (2013). Thermal insulating products for building applications - Determination of tensile strength perpendicular to faces. Beuth Verlag GmbH, Berlin.

EN 1609. (2013). Thermal insulating products for building applications - Determination of short term water absorption by partial immersion. Beuth Verlag GmbH, Berlin. 
EN 826. (2013). Thermal insulating products for building applications - Determination of compression behaviour. Beuth Verlag GmbH, Berlin.

Euring, M., \& Kharazipour, A. (2013). Verfahren zur Herstellung von Holz und/ oder Verbundwerkstoffen. Patent EP 2819819 B1.

Euring, M., Kirsch, A., \& Kharazipour, A. (2015). Hot-air/hot-steam process for the production of laccase-mediator-system bound wood fiber insulation boards. BioResources, 10(2), 3541-3552. https://doi.org/10.15376/biores.10.2.3541-3552

Fahs, A., \& Louarn, G. (2013). Plant protein interactions studied using AFM force spectroscopy: Nanomechanical and adhesion properties. Physical Chemistry Chemical Physics, 15(27), 11339-11348. https://doi.org/10.1039/c3cp51007g

FAOSTAT. (2021). Worldwide annual rapeseed production quantity for 2019. Retrieved January 4, 2021 from http://www.fao.org/faostat/en/\#data/QC

Frihart, C. R. (2013). Wood Adhesion and Adhesives. In R. M. Rowell (Ed.), Handbook of Wood Chemistry and Wood Composites (2nd ed., pp. 215-278). CRC Press Boca Raton

Frihart, C. R., \& Birkeland, M. J. (2014). Soy properties and soy wood adhesives. In R. P. Brentin (Ed.), Soy-based chemicals and materials (pp. 167-192). American Chemical Society, Washington D.C., USA. https://doi.org/10.1021/bk-2014-1178.ch008

Hale, K. (2013). The Potential of Canola Protein for Bio-Based Wood Adhesive (Master's thesis). Kansas State University, Manhattan Kansas, USA.

Hollemann, A. F., Wiberg, E., Wiberg, N., \& Fischer, G. (2017). Anorganische Chemie (103. Auflage). De Gruyter, Berlin, Germany.

Informationsdienst Holz. (2007). Holzfaserdämmstoffe - Eigenschaften, Anforderungen, Anwendungen. Verband Holzfaserdämmstoffe e. V., Wuppertal, Germany.

Kaesche, H. (1970). Elektrochemische Untersuchungen über die Korrosion des Eisens in sulfidhaltigen Lösungen. Materials and Corrosion, 21(3), 185-195. https://doi.org/10.1002/maco.19700210305

Kirsch, A., Ostendorf, K., \& Euring, M. (2018). Improvements in the production of wood fiber insulation boards using hot-air/hot-steam process. European Journal of Wood and Wood Products, 76(4), 1233-1240. https://doi.org/10.1007/s00107-018-1306-z

Lamlom, S. H., \& Savidge, R. A. (2003). A reassessment of carbon content in wood: Variation within and between 41 North American species. Biomass and Bioenergy, 25(4), 381-388. https://doi.org/10.1016/S0961-9534(03)00033-3

Landwirtschaftliche Untersuchungs- und Forschungsanstalt Nordrhein-Westfalen. (2018). Prüfbericht für Rapsexpeller im Auftrag der Kleeschulte GmbH \& Co. KG vom 26.03.2018.

Li, N., Qi, G., Sun, X. S., \& Wang, D. (2017). Canola protein and oil-based wood adhesives. In Z. He (Ed.), Bio-Based Wood Adhesives: Preparation, Characterization, and Testing (pp. 111-139). CRC Press: Boca Raton, FL, USA. https://doi.org/10.1201/9781315369242-4

Li, N., Qi, G., Sun, X. S., Stamm, M. J., \& Wang, D. (2012). Physicochemical properties and adhesion performance of canola protein modified with sodium bisulfite. Journal of the American Oil Chemists' Society, 89(5), 897-908. https://doi.org/10.1007/s11746-011-1977-7

Lundgren, Åke (1958). Die hygroskopischen Eigenschaften von Holzfaserplatten. Holz als Roh- und Werkstoff, 16(4), 122-127. https://doi.org/10.1007/BF02615507

McVetty, P. B., \& Duncan, R. W. (2015). Canola, rapeseed, and mustard: for biofuels and Bioproducts. In V. M. Cruz, \& D. A. Dierig (Eds.), Industrial Crops-Breeding for BioEnergy and Bioproducts (pp. 133-156). Springer, New York. https://doi.org/10.1007/978-1-4939-1447-0_7

Niemz, P., \& Wagenführ, A. (2018) Werkstoffe aus Holz. In A. Wagenführ, \& F. Scholz (Eds.), Taschenbuch der Holztechnik, 3. Auflage (pp. 129-261). F. Carl Hanser Verlag, München. https://doi.org/10.3139/9783446454415

Ostendorf, K., Reuter, P., \& Euring, M. (2020) Manufacturing Medium-density Fiberboards and Wood Fiber Insulation Boards Using a Blood Albumin Adhesive on a Pilot Scale. BioResources, 15(1), 1531-1546. 
Peterson, C. L., \& Hustrulid, T. (1998). Carbon Cycle for Rapeseed Oil Biodiesel Fuels. Biomass and Bioenergy, 14(2), 91-101. https://doi.org/10.1016/S0961-9534(97)10028-9

Ranjbar, Z., Sun, N., Niu, C. H., \& Dalai, A. (2013). Adsorption of Water and Ethanol by Canola Meal in a Batch Liquid System (pp. 1-10). Canadian Society for Bioengineering, University of Saskatchewan, Saskatoon, SK, Canada.

Raymer, P. L. (2002). Canola: An emerging oilseed crop. In J. Janick, \& A. Whipkey (Eds.), Trends in new crops and new uses (pp. 122-126). ASHS Press, Alexandria, Virginia, USA.

Sun, X. S. (2005). Soy Protein Adhesives. In R. P. Wool, \& X. S. Sun (Eds.), Bio-Based Polymers and Composites - 1st Edition (pp. 327-368). Academic Press, Cambridge, Massachusetts, USA. https://doi.org/10.1016/B978-012763952-9/50011-3

TAPPI. (1985). Test method $223 \mathrm{~cm}-01$ : Pentosans in wood and pulp. Atlanta, USA.

Tsoumis, G. (1991) Science and technology of wood. Structure, properties, utilization (Vol. 115). New York: Van Nostrand Reinhold.

Türk, O. (2014). Stoffliche Nutzung nachwachsender Rohstoffe, Grundlagen-Werkstoffe-Anwendungen. Springer Fachmedien, Wiesbaden, Germany. https://doi.org/10.1007/978-3-8348-2199-7

Van Zeist, W. J., Marinussen, M., Broekema, R., Groen, E., Kool, A., Dolman, M., \& Blonk, H. (2012). LCI data for the calculation tool Feedprint for greenhouse gas emissions of feed production and utilization, GHG Emissions of N, $P$ and $K$ fertiliser production.

Von der Haar, D., Müller, K., Bader-Mittermaier, S., \& Eisner, P. (2014). Rapeseed proteins - Production methods and possible application ranges. Oilseeds and fats, Crops and Lipids, 21(1), 1-8. https://doi.org/10.1051/ocl/2013038

Wang, C., Wu, J., \& Bernard, G. M. (2014). Preparation and characterization of canola protein isolate-poly (glycidyl methacrylate) conjugates: A bio-based adhesive. Industrial Crops and Products, 57, 124-131. https://doi.org/10.1016/j.indcrop.2014.03.024

Yang, I., Han, G. S., Ahn, S. H., Choi, I. G., Kim, Y. H., \& Oh, S. C. (2014). Adhesive properties of medium-density fiberboards fabricated with rapeseed flour-based adhesive resins. The Journal of Adhesion, 90(4), 279-295. https://doi.org/10.1080/00218464.2013.793161

Yang, I., Han, G. S., Choi, I. G., Kim, Y. H., Ahn, S. H., \& Oh, S. C. (2011). Development of Adhesive Resins Formulated with Rapeseed Flour Hydrolyzates for Laminated Veneer Lumber and Its Performance Evaluation. Journal of the Korean Wood Science and Technology, 39(3), 221-229. https://doi.org/10.5658/WOOD.2011.39.3.229

Yang, I., Han, G. S., Choi, I. G., Kim, Y. H., Ahn, S. H., \& Oh, S. C. (2012). Development of Adhesive Resins Formulated with Rapeseed Flour Hydrolyzates for Medium Density Fiberboard (MDF). Journal of the Korean Wood Science and Technology, 40(3), 177-185. https://doi.org/10.5658/WOOD.2012.40.3.177

Yang, I., Jeong, J. H., Han, G. S., Cho, I. G., SaGong, M., Ahn, S. H., \& Oh, S. C. (2010). Development of adhesive resins formulated with rapeseed flour akali hydrolyzates for plywood panels. Journal of the Korean Wood Science and Technology, 38(4), 323-332. https://doi.org/10.5658/WOOD.2010.38.4.323

Zhou, X., \& Frazier, C. E. (2001). Double labeled isocyanate resins for the solid-state NMR detection of urethane linkages to wood. International Journal of Adhesion and Adhesives, 21(3), 259-264. https://doi.org/10.1016/S0143-7496(01)00013-6

\section{Copyrights}

Copyright for this article is retained by the author(s), with first publication rights granted to the journal.

This is an open-access article distributed under the terms and conditions of the Creative Commons Attribution license (http://creativecommons.org/licenses/by/4.0/). 